Article

\title{
Simultaneous hydrogen and peroxide production by photocatalytic water splitting
}

\author{
Lichao Wang a,b,t, Shuang Cao a,t, Kai Guo a, Zhijiao Wu a, Zhi Ma b,*, Lingyu Piao a,\# \\ a CAS Center for Excellence in Nanoscience, National Center for Nanoscience and Technology, CAS Key Laboratory of Standardization and Measurement \\ for Nanotechnology, Beijing 100190, China \\ b School of chemical Engineering and Technology, Tianjin University, Tianjin 300072, China
}

\section{A R T I C L E I N F 0}

\section{Article history:}

Received 5 November 2018

Accepted 7 December 2018

Published 5 March 2019

\section{Keywords:}

Photocatalytic water splitting

Hydrogen

Hydrogen peroxide

Anatase $\mathrm{TiO}_{2}$

\begin{abstract}
A B S T R A C T
Photocatalytic oxidation of water is a promising method to realize large-scale $\mathrm{H}_{2} \mathrm{O}_{2}$ production without a hazardous and energy-intensive process. In this study, we introduce a $\mathrm{Pt} / \mathrm{TiO}_{2}$ (anatase) photocatalyst to construct a simple and environmentally friendly system to achieve simultaneous $\mathrm{H}_{2}$ and $\mathrm{H}_{2} \mathrm{O}_{2}$ production. Both $\mathrm{H}_{2}$ and $\mathrm{H}_{2} \mathrm{O}_{2}$ are high-value chemicals, and their separation is automatic. Even without the assistance of a sacrificial agent, the system can reach an efficiency of 7410 and $5096 \mu \mathrm{mol} \mathrm{g}^{-1} \mathrm{~h}^{-1}$ (first $1 \mathrm{~h}$ ) for $\mathrm{H}_{2}$ and $\mathrm{H}_{2} \mathrm{O}_{2}$, respectively, which is much higher than that of a commercial $\mathrm{Pt} / \mathrm{TiO}_{2}$ (anatase) system that has a similar morphology. This exceptional activity is attributed to the more favorable two-electron oxidation of water to $\mathrm{H}_{2} \mathrm{O}_{2}$, compared with the four-electron oxidation of water to $\mathrm{O}_{2}$.
\end{abstract}

(C) 2019, Dalian Institute of Chemical Physics, Chinese Academy of Sciences. Published by Elsevier B.V. All rights reserved.

\section{Introduction}

$\mathrm{H}_{2} \mathrm{O}_{2}$ is not only a high-value industrial chemical, in growing demand on the global market, but also a potentially attractive energy carrier $[1,2] . \mathrm{H}_{2} \mathrm{O}_{2}$ is widely used in chemical synthesis, disinfection, wastewater treatment, pulp, etc. [3] Moreover, due to the advantage of a simple membrane-free structure, hydrogen peroxide fuel cells have attracted extensive attention $[4,5]$. The traditional method for $\mathrm{H}_{2} \mathrm{O}_{2}$ production has been the anthraquinone process, which is an indirect batch method requiring sequential hydrogenation, oxidation of a 2-alkylanthraquinone, and extraction of $\mathrm{H}_{2} \mathrm{O}_{2}$ from organic solvents [6]. However, this multistep method is hazardous, energy-intensive, and difficult for in situ $\mathrm{H}_{2} \mathrm{O}_{2}$ production. Thus, extensive efforts have been devoted to achieving direct synthesis of $\mathrm{H}_{2} \mathrm{O}_{2}$ by eco-friendly and low-cost processes [7]. $\mathrm{H}_{2} \mathrm{O}_{2}$ production by photocatalytic methods, which are powered by clean solar energy, is considered one of the most promising approaches. To date, photocatalysis has been studied in many fields, including hydrogen production, $\mathrm{CO}_{2}$ reduction, and water treatment [8-24]. However, there is still a great deal of potential for photocatalytic $\mathrm{H}_{2} \mathrm{O}_{2}$ production. Recently, intense efforts have been made to achieve $\mathrm{H}_{2} \mathrm{O}_{2}$ production by photocatalytic $\mathrm{O}_{2}$ reduction $[25,26]$. However, research concerning simultaneous $\mathrm{H}_{2}$ and $\mathrm{H}_{2} \mathrm{O}_{2}$ production during water splitting is scarce. Compared with the traditional four-electron transfer process, converting water to $\mathrm{H}_{2}$ and $\mathrm{H}_{2} \mathrm{O}_{2}$ by a two-electron/two-proton oxidation process is considered as the ideal method, in which

\footnotetext{
*Corresponding author. Tel: +86-22-27403389; E-mail: mazhi@tju.edu.cn

\# Corresponding author. Tel: +86-10-82545653; E-mail: piaoly@nanoctr.cn

†These authors contributed equally to this work.

This work was supported by the National Natural Science Foundation of China (21703046) and the National Key R\&D of China (2016YFF0203803 and 2016YFA0200902).

DOI: S1872-2067(19)63274-2 | http://www.sciencedirect.com/science/journal/18722067 | Chin. J. Catal., Vol. 40, No. 3, March 2019
} 
all the products are value-added chemicals [27]. Moreover, the system avoids the problem of separation because $\mathrm{H}_{2}$ and $\mathrm{H}_{2} \mathrm{O}_{2}$ exist in gas and liquid phases, respectively, which is a significant advantage over the $\mathrm{H}_{2}$ and $\mathrm{O}_{2}$ production system. To date, fewer catalysts are known for the selective two-electron oxidation of water to produce hydrogen peroxide, compared with the four-electron oxidation of water to produce oxygen [28,29]. To the best of our knowledge, two systems, Pt/P25 [30] and $\mathrm{Pt} / \mathrm{C}_{3} \mathrm{~N}_{4}$ [31] have been reported for photocatalytic hydrogen and hydrogen peroxide production from pure water. However, the catalytic efficiency is still very low. The $\mathrm{H}_{2}$ and $\mathrm{H}_{2} \mathrm{O}_{2}$ evolution rates are $42.75 \mu \mathrm{mol} \mathrm{g}^{-1} \mathrm{~h}^{-1}$ (first $30 \mathrm{~min}$ ) and $34.38 \mu \mathrm{mol}$ $\mathrm{g}^{-1} \mathrm{~h}^{-1}$ (average of $2 \mathrm{~h}$ ), and $10.80 \mu \mathrm{mol} \mathrm{g}^{-1} \mathrm{~h}^{-1}$ (average of $25 \mathrm{~h}$ ) and $13.80 \mu \mathrm{mol} \mathrm{g}^{-1} \mathrm{~h}^{-1}$ (average of $25 \mathrm{~h}$ ), for Pt/P25 and $\mathrm{Pt} / \mathrm{C}_{3} \mathrm{~N}_{4}$, respectively.

In this study, we introduce $\mathrm{Pt} / \mathrm{TiO}_{2}$ (anatase) as a photocatalyst, which produces hydrogen in the gas phase, and $\mathrm{H}_{2} \mathrm{O}_{2}$ on the surface of catalyst and in solution. The $\mathrm{H}_{2}$ and $\mathrm{H}_{2} \mathrm{O}_{2}$ production efficiencies can reach up to 7410 and $5096 \mu \mathrm{mol} \mathrm{g-1}$ $\mathrm{h}^{-1}$ (first $1 \mathrm{~h}$ ), respectively, without the assistance of a sacrificial agent. The $\mathrm{H}_{2}$ production efficiency is 173 and 686 times higher than those of the Pt/P25 and $\mathrm{Pt} / \mathrm{C}_{3} \mathrm{~N}_{4}$ systems, respectively. Additionally, the $\mathrm{H}_{2} \mathrm{O}_{2}$ production efficiency is 148 and 369 times higher than those of the Pt/P25 and Pt/ $\mathrm{C}_{3} \mathrm{~N}_{4}$ systems, respectively. Therefore, it is clear that the present system is promising for production of high value-added chemicals by photocatalytic water splitting.

\section{Experimental}

\subsection{Materials}

All chemical reagents were analytical grade and used without further purification. Ethylalcohol, methanol, silver nitrate $\left(\mathrm{AgNO}_{3}\right)$, ammonia solution and titanium tetrachloride $\left(\mathrm{TiCl}_{4}\right)$ were obtained from Beijing Sinopharm Chemical Reagent Co., Ltd. $\mathrm{H}_{2} \mathrm{PtCl}_{6}$ was obtained from J\&K Scientific Ltd.

\subsection{Preparation of $\mathrm{TiO}_{2} \mathrm{NPS}$}

A solution of $0.2 \mathrm{~mol} / \mathrm{L} \mathrm{TiCl}_{4}$ was slowly dropped into a 0.5 $\mathrm{mol} / \mathrm{L}$ ammonia solution $(50 \mathrm{~mL})$ under vigorous stirring at room temperature until the $\mathrm{pH}$ value of the solution reached $\sim 8$. A white precipitate was formed and then centrifuged and washed with distilled water until chloride ions were not detectable in the washed water (1.0 wt $\% \mathrm{AgNO}_{3}$ solution). A quarter of the precipitation was dispersed in $50 \mathrm{ml}$ of anhydrous ethylalcohol by ultrasonic treatment for $20 \mathrm{~min}$ in an autoclave, and was kept at $150{ }^{\circ} \mathrm{C}$ for $5 \mathrm{~h}$. The products were collected and washed with deionized water three times. After that, the samples were dried and calcined at $400{ }^{\circ} \mathrm{C}$ for $2 \mathrm{~h}$. The Pt NPs were loaded by an in-situ photo-depostion method using $\mathrm{H}_{2} \mathrm{PtCl}_{6}$ (Pt $1 \mathrm{wt} \%$ in the whole sample) as the precusor and $\mathrm{MeOH}$ as the electron donor (10\%). After $1 \mathrm{~h}$ of UV light irradiation, the sample was collected by centrifugation and dried at $80^{\circ} \mathrm{C}$ overnight to remove the remaining $\mathrm{MeOH}$ and $\mathrm{H}_{2} \mathrm{O}$.

\subsection{Photocatalytic reaction}

The prepared $\mathrm{Pt} / \mathrm{TiO}_{2}$ hybrid (1 $\mathrm{mg}$ ) was dispersed in $20 \mathrm{~mL}$ deionized water in a quartz reactor and sealed with a rubber septum. After purging with argon flow for $30 \mathrm{~min}$ to remove dissolved air, the suspensions were irradiated by a $500 \mathrm{~W} \mathrm{Hg}$ lamp under magnetic stirring at room temperature. The evolved $\mathrm{H}_{2}$ in the gas phase was examined by a Techcomp gas chromatograph (GC-7900) with a thermal conductivity detector (TCD), 5 Å molecular sieve columns, and Ar carrier.

\subsection{The $\mathrm{H}_{2} \mathrm{O}_{2}$ test method}

The hydrogen peroxide measurement was performed in 2.0 $\mathrm{mL}$ reaction suspension. A $0.5 \mathrm{~mL}$ volume indicator $(1 \%$ $o$-tolidine in $0.1 \mathrm{~mol} / \mathrm{L} \mathrm{HCl}$ ) was added to the suspension and the mixture was allowed to react for $10 \mathrm{~min}$. The color of the mixture turns to blue. Subsequently, $2.0 \mathrm{~mL} \mathrm{HCl}(1.0 \mathrm{~mol} / \mathrm{L})$ was added to the mixture, and the color turns to yellow from blue. Immediately, the mixture was centrifuged and the absorption spectrum of the liquid supernatant was recorded with a UV-vis spectrophotometer. The absorption spectrum of the 2-electron oxidized toluidine has a characteristic maximum at $437 \mathrm{~nm}$.

\subsection{Characterization of samples}

UV-Vis spectra were measured with a Hitachi U-3900 spectrophotometer. Scanning electron microscopy (SEM) images were taken by using a Zeiss electron microscope. Transmission electron microscopy (TEM) images were obtained by using a 2100F (JEOL) electron microscope at an acceleration voltage of $200 \mathrm{kV}$. X-ray diffraction (XRD) of the samples was performed with a SmartLab Goniometer with $\mathrm{Cu}$ K-beta radiation, operating at $40 \mathrm{kV}$ and $200 \mathrm{~mA}$. X-ray photoelectron spectroscopy (XPS) analysis was carried out on a Thermo Scientific ESCALAB 250Xi spectrometer (all the peaks corrected with reference to the C signal (284.8 eV)). Raman spectrum was recorded on a Renishaw inVia Raman microspectrometer and laser excitation wavelength was $633 \mathrm{~nm}$. The static fluorescence spectral measurements were carried out with an F-4600 (Hitachi) spectrofluorometer. The ESR measurements were conducted by a Bruker ESP-300E spectrometer at $9.8 \mathrm{GHz}$, X-band, with $100 \mathrm{~Hz}$ field modulation.

\subsection{Calculation of the valence band of $\mathrm{TiO}_{2}$}

The valence band of titanium oxide was calculated by the theory of elemental electronegativity. The valence band is calculated by using element electronegativity and material's band gap which comes from the UV-vis diffuse reflectance spectra.

$$
\begin{gathered}
E_{\mathrm{c}}=-\left[\chi(\mathrm{A})^{a} \cdot \chi(\mathrm{B})^{b} \cdot \chi(\mathrm{C})^{\mathrm{c}}\right]^{1 /(a+b+c)}+1 / 2 E_{\mathrm{g}}+E_{0} \\
E_{\mathrm{v}}=E_{\mathrm{c}}+E_{\mathrm{g}}
\end{gathered}
$$

Where $\chi(\mathrm{A})$ is the absolute electronegativity of element $\mathrm{A}, E_{\mathrm{g}}$ is the band gap, and $E_{0}$ is the reduction potential of water (4.5 $\mathrm{eV})$. 

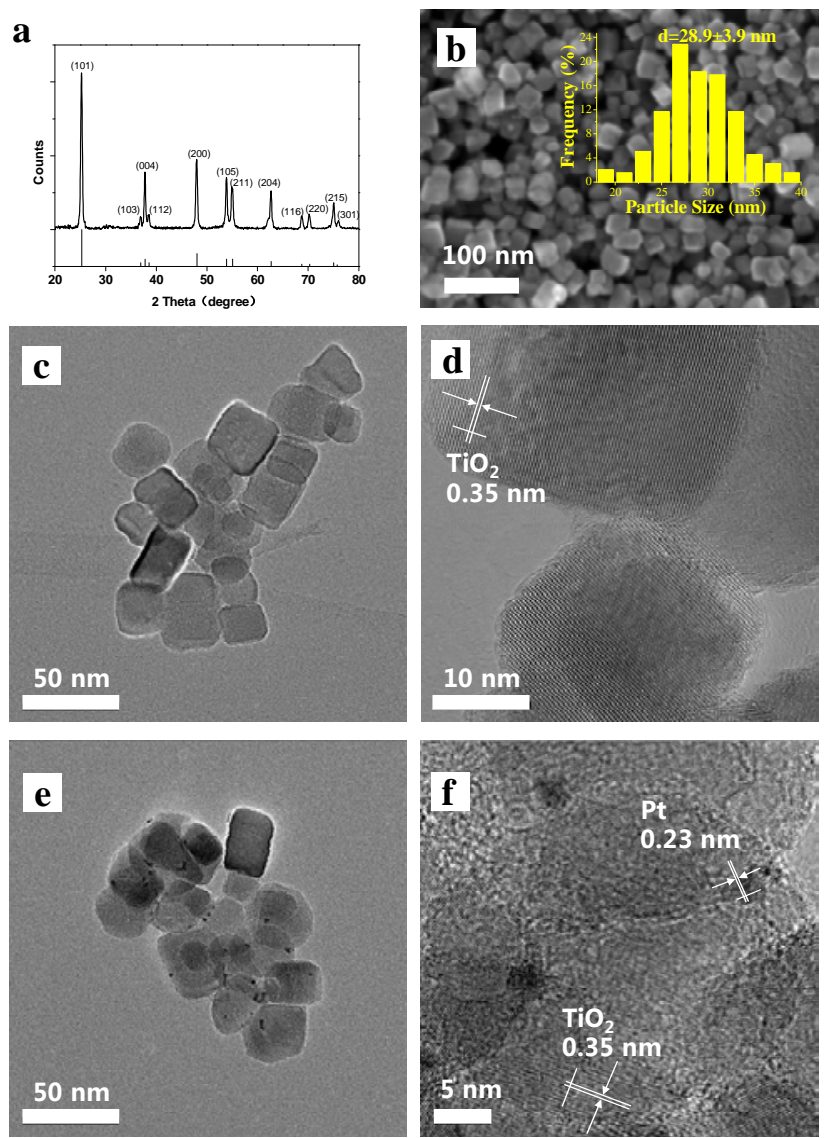

Fig. 1. (a) XRD pattern and (b) SEM images for the $\mathrm{TiO}_{2} \mathrm{NPs}$; TEM and HRTEM images for the (c, d) pure $\mathrm{TiO}_{2} \mathrm{NPs}$ and (e, f) $\mathrm{Pt} / \mathrm{TiO}_{2}$ hybrid.

\section{Results and discussion}

The anatase $\mathrm{TiO}_{2}$ nanoparticles (NPs), with an average diameter of $28.9 \pm 3.9 \mathrm{~nm}$, were obtained by an improved hydrothermal strategy, in which $\mathrm{TiCl}_{4}$ was selected as the Ti precursor [32]. To construct the $\mathrm{Pt} / \mathrm{TiO}_{2}$ hybrid, Pt nanoparticles (NPs) were loaded onto the $\mathrm{TiO}_{2}$ NPs by in situ pho- to-deposition [33]. The weight of the Pt NPs was $1.0 \mathrm{wt} \%$ compared with the $\mathrm{TiO}_{2}$ NPs. Both XRD and Raman spectra show a single-phase diffraction pattern assigned to anatase $\mathrm{TiO}_{2}$ (Fig. 1a) (JCPDS No. 21-1272). Five main diffraction peaks near or at $2 \theta=25.3^{\circ}, 37.8^{\circ}, 48.0^{\circ}, 53.9^{\circ}$, and $55.1^{\circ}$ are observed, corresponding to the (101), (004), (200), (105) and (211) diffraction planes of anatase $\mathrm{TiO}_{2}$, respectively [34]. The Raman shifts of 397, 516 and $639 \mathrm{~cm}^{-1}$ correspond to anatase $\mathrm{TiO}_{2}$ (Fig. S1) [35]. The morphology of the $\mathrm{TiO}_{2}$ catalyst was characterized by SEM and TEM (Fig. 1b-f). As shown in Fig. 1b, the $\mathrm{TiO}_{2}$ NPs display a spherical morphology with an average diameter of $28.9 \pm 3.9 \mathrm{~nm}$, from the SEM image statistics. The lattice spacing is $0.35 \mathrm{~nm}$, which is assigned to the (101) crystal plane of anatase $\mathrm{TiO}_{2}$, from the TEM images (Fig. 1c-d). For the Pt/TiO hybrid (Fig. 1e), the Pt NPs, with a size of $2 \mathrm{~nm}$, are well dispersed onto $\mathrm{TiO}_{2}$. The $d$-spacings of 0.35 and $0.23 \mathrm{~nm}$ correspond to the (101) and (111) planes of $\mathrm{TiO}_{2}$ and $\mathrm{Pt}$, respectively [36].

The photocatalytic performance of the catalysts was evaluated under $\mathrm{Hg}$ lamp irradiation $(\lambda \geq 300 \mathrm{~nm})$ at room temperature. As shown in Fig. 2a, our system achieved the highly efficient $\mathrm{H}_{2}$-production activity of $7410 \mu \mathrm{mol} \mathrm{g}^{-1} \mathrm{~h}^{-1}$ for the first 1 $h$, in deionized water, without an electron sacrificial agent. The produced $\mathrm{H}_{2} \mathrm{O}_{2}$ was measured using the peroxide indicator $o$-tolidine, after a period of irradiation, and a typical absorption peak at $437 \mathrm{~nm}$ was easily detected using UV-vis spectroscopy [31]. As depicted in Fig. S2, the $\mathrm{H}_{2} \mathrm{O}_{2}$ production efficiency is $5096 \mu \mathrm{mol} \mathrm{g}^{-1} \mathrm{~h}^{-1}$. In contrast, the commercial Pt/anatase $\mathrm{TiO}_{2}$ hybrid only exhibits an efficiency of $3041 \mu \mathrm{mol} \mathrm{g}^{-1} \mathrm{~h}^{-1}$ and 2644 $\mu \mathrm{mol} \mathrm{g}{ }^{-1} \mathrm{~h}^{-1}$ for $\mathrm{H}_{2}$ and $\mathrm{H}_{2} \mathrm{O}_{2}$, respectively (Fig. 2a). It should be noted that the commercial anatase $\mathrm{TiO}_{2}$ NPs have a similar morphology to our system (Figs. S3-5), and, as shown in Fig. S6, the average pore sizes and Brunauer-Emmett-Teller (BET) surface areas were determined to be $18.2 \mathrm{~nm}$ and $46.0 \mathrm{~m}^{2} / \mathrm{g}$ for the present sample, and $17.8 \mathrm{~nm}$ and $53.8 \mathrm{~m}^{2} / \mathrm{g}$ for the commercial anatase $\mathrm{TiO}_{2} \mathrm{NPs}$, respectively, by $\mathrm{N}_{2}$ adsorption. The results indicate that the difference in surface area does not lead to the difference in photocatalytic efficiency. Therefore, compared with the commercial $\mathrm{Pt} /$ anatase $\mathrm{TiO}_{2}$, the present system

b
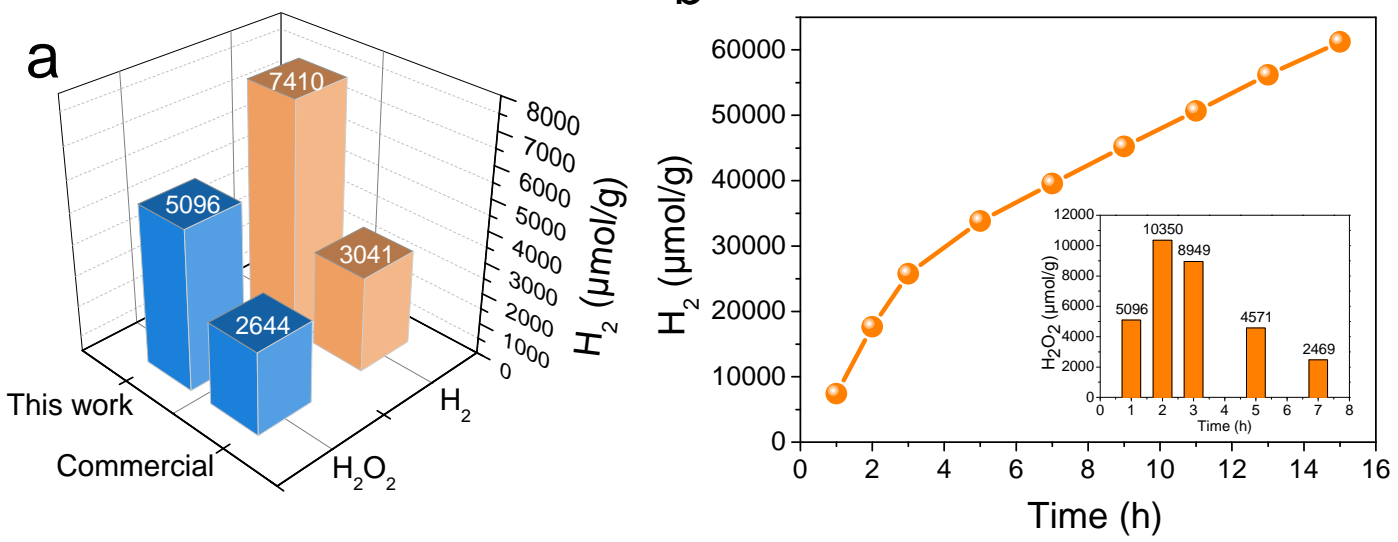

Fig. 2. (a) Activity comparisons between the present anatase $\mathrm{TiO}_{2} \mathrm{NPs}$ and commercial anatase $\mathrm{TiO}_{2} \mathrm{NPs}$ with a similar morphology (all photocatalyst samples weighed $1 \mathrm{mg}$ and contained $1.0 \mathrm{wt} \% \mathrm{Pt} \mathrm{NPs}$ ); (b) Stability evaluation of $\mathrm{Pt}^{\mathrm{TiO}} \mathrm{Ti}_{2}$ for $\mathrm{H}_{2}$ and $\mathrm{H}_{2} \mathrm{O}_{2}$ (inset) production. All the experiments were conducted in $20 \mathrm{~mL}$ deionized water with $1 \mathrm{mg} \mathrm{Pt}(1.0 \mathrm{wt} \%) / \mathrm{TiO}_{2}$ hybrid photocatalyst. 
demonstrates significant advantages not only in $\mathrm{H}_{2}$ evolution, but also in $\mathrm{H}_{2} \mathrm{O}_{2}$ production. To demonstrate the potential value in practical applications, a photocatalytic stability experiment was carried out. As depicted in Fig. 2b, the photocatalytic hydrogen evolution activity could be sustained for more than 15 $\mathrm{h}$, and more than $61723 \mu \mathrm{mol} / \mathrm{g} \mathrm{H}_{2}$ was produced. The amount of $\mathrm{H}_{2} \mathrm{O}_{2}$ initially increased, and then decreased with an increase in irradiation time. It was proposed that $\mathrm{H}_{2} \mathrm{O}_{2}$ could decompose to $\mathrm{H}_{2} \mathrm{O}$ and $\mathrm{O}_{2}$ under prolonged irradiation. However, no oxygen was detected during the photocatalytic reaction, and hydrogen peroxide $\left(\mathrm{H}_{2} \mathrm{O}_{2}\right)$ was detected as the only oxidative product. The produced $\mathrm{O}_{2}$ could be easily reduced by the photo-generated electrons, and further mechanistic studies are ongoing. Collectively, these results indicate that the present photocatalytic system is highly efficient and promising for $\mathrm{H}_{2}$ and $\mathrm{H}_{2} \mathrm{O}_{2}$ production without separation problems.

For the water splitting reaction $\left(2 \mathrm{H}_{2} \mathrm{O} \rightarrow \mathrm{H}_{2}+\mathrm{H}_{2} \mathrm{O}_{2}\right)$, it is widely accepted that $\mathrm{H}_{2}$ is generated on $\mathrm{Pt}$ [37]. For the mechanism of $\mathrm{H}_{2} \mathrm{O}_{2}$ formation, it has been proposed that $\mathrm{H}_{2} \mathrm{O}_{2}$ is mainly derived from the recombination of hydroxyl radicals $(\bullet \mathrm{OH})$. During the photocatalytic reaction, $\bullet \mathrm{OH}$ is confirmed as the crucial reactive intermediate. To gain insight into the process, XPS measurements were first used to investigate the surface properties of the $\mathrm{TiO}_{2}$ NPs (Figs. S7-10). Before irradiation, $\mathrm{TiO}_{2}$ and $\mathrm{Pt} / \mathrm{TiO}_{2}$ samples show two main peaks, corresponding to surface lattice oxygen (529.7 eV, $529.8 \mathrm{eV})$ and surface hydroxyls $(531.6 \mathrm{eV}, 531.9 \mathrm{eV})$. At the same time, for the $\mathrm{Pt} / \mathrm{TiO}_{2}$ sample, a weak peak near $533.3 \mathrm{eV}$, associated with physisorbed water is observed. After $1 \mathrm{~h}$ of irradiation, there is a distinct change in the spectrum. The peak at $533.2 \mathrm{eV}$, associated with physisorbed water, is greatly enhanced, and the hydroxyl peak is significantly increased, compared with the other samples (Fig. 3a) [38,39]. In contrast, Ti atoms demonstrate a similar bonding environment before and after irradiation (Fig. $3 b)$. The binding energies of Ti $2 p_{3 / 2}$ and $2 p_{1 / 2}, 458.6$ and 464.4 eV, respectively, are the characteristic peaks of $\mathrm{Ti}^{4+}$ in $\mathrm{TiO}_{2}$ [40]. Therefore, it is proposed that the hydroxyls and adsorbed water have a significant impact on the formation of $\mathrm{H}_{2} \mathrm{O}_{2}$. In order to capture the reactive intermediate during the irradiation reaction, electron spin resonance (ESR) and fluorescence labeling measurements were performed. As shown in Fig. 3c, a characteristic quartet of peaks $\left(1: 2: 2: 1, a_{\mathrm{N}}=a_{\mathrm{H}}=15.4 \mathrm{G}\right)$ associated with the 5,5-dimethyl-1-pyrroline- $\mathrm{N}$-oxide-OH (DMPO-OH) radical adduct is immediately detected after $60 \mathrm{~s}$ of UV light irradiation [41]. Additionally, when terephthalate (TANa) was added to the system, an obvious fluorescence signal at $422 \mathrm{~nm}$, assigned to 2-hydroxyterephthalic acid (TAOH), was detected (Fig. 3d) [42]. The ESR and fluorescence results imply that the generated $\bullet \mathrm{OH}$ radicals play a significant role in the formation of $\mathrm{H}_{2} \mathrm{O}_{2}$ [30]. The bandgap and valence band for the present anatase $\mathrm{TiO}_{2}$ are 3.21 and $2.97 \mathrm{eV}$, respectively, confirmed by diffuse reflectance UV-vis spectroscopy (Fig. 3e). The oxidation potentials $E_{\mathrm{ox}}\left(\bullet \mathrm{OH} / \mathrm{OH}^{-}\right)$and $E_{\mathrm{ox}}\left(\bullet \mathrm{OH}_{\mathrm{ads}} / \mathrm{OH}^{-}\right.$ads $)$are 1.89 and $1.5 \mathrm{~V}$ versus the NHE, respectively $[43,44]$. Therefore, the $\mathrm{H}^{+}$ photogenerated by the anatase $\mathrm{TiO}_{2}$ has enough oxidation potential to convert $\bullet \mathrm{OH}$ to $\mathrm{OH}^{-}$and $\mathrm{OH}^{-}$ads to $\bullet \mathrm{OH}_{\text {ads. }}$ Furthermore, compared with the commercial anatase $\mathrm{TiO}_{2} \mathrm{NP}$ sample, the present anatase NPs possess more hydroxyls and adsorbed
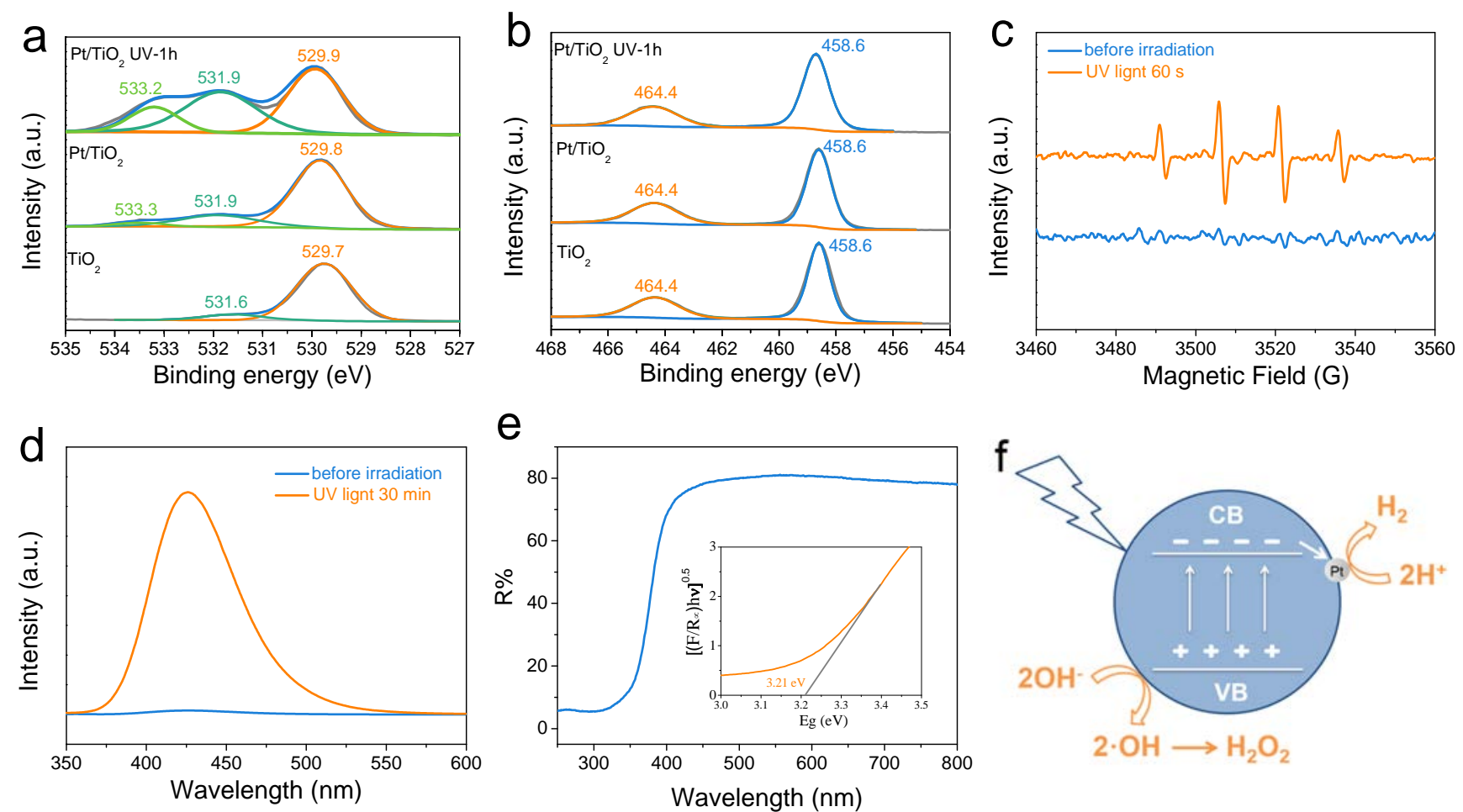

e
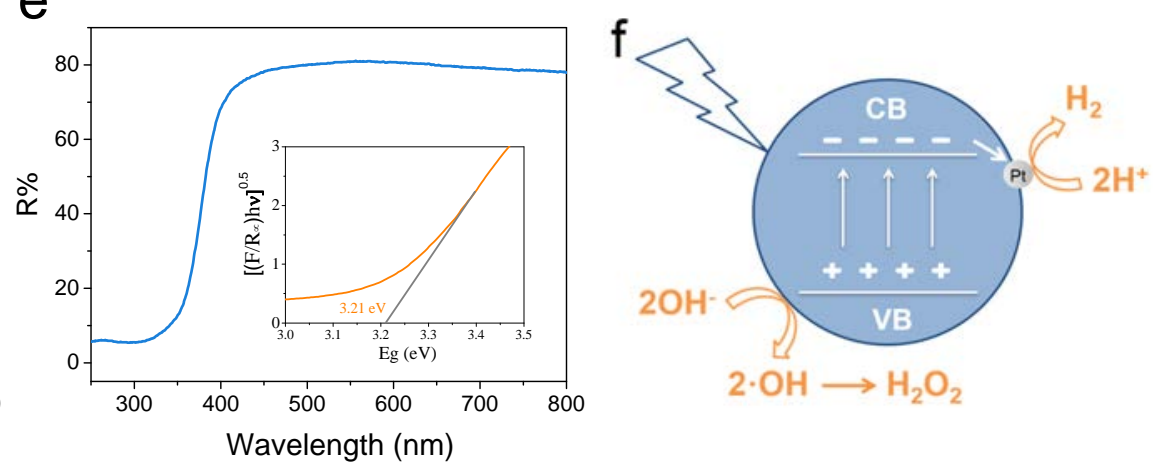

Fig. 3. XPS spectra of (a) $01 s$ and (b) $\mathrm{Ti} 2 p$ in $\mathrm{TiO}_{2}$, $\mathrm{Pt} / \mathrm{TiO}_{2}$, and $\mathrm{Pt} / \mathrm{TiO}_{2}$ (UV light $1 \mathrm{~h}$ ), respectively; (c) ESR spectra for $\bullet \mathrm{OH}$ radical detection in the presence of $\mathrm{Pt} / \mathrm{TiO}_{2}$ and $\mathrm{DMPO}$ in aqueous solution under UV light irradiation; (d) Fl spectra for $\bullet \mathrm{OH}$ radical detection using TAOH as the trapping agent; (e) Diffuse reflectance spectrum of the $\mathrm{TiO}_{2}$ sample (insert: the transformed Kubelka-Munk function versus band gap); (f) Schematic of the mechanism for photocatalytic water splitting into $\mathrm{H}_{2}$ and $\mathrm{H}_{2} \mathrm{O}_{2}$. 
water (Fig. S11). Therefore, it can be concluded that the surface properties, and the quantities of hydroxyls and physisorbed water are related to the catalytic performance. Based on the above analysis, the reaction mechanism is depicted in Fig. 3f. To date, different oxidation products have been reported for photocatalytic water splitting using anatase. No oxygen was detected, or the final ratios of $\mathrm{H}_{2} / \mathrm{O}_{2}$ were below $2[28,29,45]$. Therefore, water oxidation products other than oxygen play a significant role. In the present $\mathrm{Pt} / \mathrm{TiO}_{2}$ (anatase) system, we detected $\mathrm{H}_{2} \mathrm{O}_{2}$ as the water oxidation product, and further mechanistic investigation is underway.

\section{Conclusions}

We have developed a much more valuable and efficient photocatalytic water splitting system by converting water to $\mathrm{H}_{2}$ and $\mathrm{H}_{2} \mathrm{O}_{2}$ simultaneously. The stable and easily-prepared $\mathrm{Pt} /$ $\mathrm{TiO}_{2}$ (anatase) hybrid is introduced as the catalyst. The $\mathrm{H}_{2}$ and $\mathrm{H}_{2} \mathrm{O}_{2}$ production rates can reach up to 7410 and $5096 \mu \mathrm{mol} \mathrm{g}-1$ $h^{-1}$. More importantly, $\mathrm{H}_{2}$ and $\mathrm{H}_{2} \mathrm{O}_{2}$ are separated automatically, avoiding additional separation costs. The excellent activity is attributed to the more favored two-electron oxidation of water to $\mathrm{H}_{2} \mathrm{O}_{2}$, compared with the four-electron oxidation of water to $\mathrm{O}_{2}$. Therefore, photocatalytic oxidation of water to $\mathrm{H}_{2} \mathrm{O}_{2}$ is a promising method to achieve large-scale $\mathrm{H}_{2}$ and $\mathrm{H}_{2} \mathrm{O}_{2}$ production without a hazardous and energy-intensive process.

\section{References}

[1] S. Fukuzumi, Y. M. Lee, W. Nam, Chem.-Eur. J., 2018, 24, 5016-5031.

[2] B. Puértolas, A. K. Hill, T. García, B. Solsona, L. Torrente-Murciano, Catal. Today, 2015, 248, 115-127.

[3] M. N. Young, M. J. Links, S. C. Popat, B. E. Rittmann, C. I. Torres, ChemSusChem, 2016, 9, 3345-3352.

[4] K. Mase, M. Yoneda, Y. Yamada, S. Fukuzumi, Nat. Commun., 2016, 7,11470-11476.

[5] Y. Yamada, M. Yoneda, S. Fukuzumi, Energy Environ. Sci., 2015, 8, 1698-1701.

[6] R. Ciriminna, L. Albanese, F. Meneguzzo, M. Pagliaro, ChemSus-
Chem, 2016, 9, 3374-3381.

[7] S. Yang, A. Verdaguer-Casadevall, L. Arnarson, L. Silvioli, V. Čolić, R. Frydendal, J. Rossmeisl, I. Chorkendorff, I. E. L. Stephens, ACS Catal., 2018, 8, 4064-4081.

[8] M. C. Wu, K. C. Hsiao, Y. H. Chang, S. H. Chan, Appl. Surf. Sci., 2018, 430, 407-414.

[9] D. Ni, H. Shen, H. Li, Y. Ma, T. Zhai, Appl. Surf. Sci., 2017, 409, 241-249.

[10] F. Li, Q. Gu, Y. Niu, R. Wang, Y. Tong, S. Zhu, H. Zhang, Z. Zhang, X. Wang, Appl. Surf. Sci., 2017, 391, 251-258.

[11] Z. Jiang, M. A. Isaacs, Z. W. Huang, W. Shangguan, Y. Deng, A. F. Lee, ChemCatChem, 2017, 9, 4268-4274.

[12] P. Devaraji, W. K. Jo, ChemCatChem, 2018, 10, 3813-3823.

[13] W. Chen, Y. Wang, S. Liu, L. Gao, L. Mao, Z. Fan, W. Shangguan, Z. Jiang, Appl. Surf. Sci., 2018, 445, 527-534.

[14] F. Chen, W. Luo, Y. Mo, H. Yu, B. Cheng, Appl. Surf. Sci., 2018, 430, 448-456.

[15] S. Wei, S. Ni, X. Xu, Chin. J. Catal., 2018, 39, 510-516.

[16] J. Wen, X. Li, W. Liu, Y. Fang, J. Xie, Y. Xu, Chin. J. Catal., 2015, 36, 2049-2070.

[17] L. Pan, J. Zhang, X. Jia, Y. H. Ma, X. Zhang, L. Wang, J. Zou, Chin. J. Catal., 2017, 38, 253-259.

[18] K. Qi, B. Cheng, J. Yu, W. Ho, Chin. J. Catal., 2017, 38, 1936-1955.

[19] C. Zhang, L. Tian, L. Chen, X. Li, K. Lv, K. Deng, Chin. J. Catal., 2018, 39, 1373-1383.

[20] F. Xu, L. Zhang, B. Cheng, J. Yu, ACS Sustainable Chem. Eng., 2018, 6, 12291-12298.

[21] A. Meng, J. Zhang, D. Xu, B. Cheng, J. Yu, Appl. Catal. B, 2016, 198, 286-294.

[22] J. Chen, T. Ding, J. Cai, Y. Wang, M. Wu, H. Zhang, W. Zhao, Y. Tian, X. Wang, X. Li, Appl. Surf. Sci., 2018, 453, 101-109.

[23] L. Kong, X. Zhang, C. Wang, F. Wan, L. Li, Chin. J. Catal., 2017, 38, 2120-2131.

[24] Q. F. Liu, Q. Zhang, B. R. Liu, S. Li, I. J. Ma, Chin. J. Catal., 2018, 39, 542-548.

[25] Y. Kofuji, S. Ohkita, Y. Shiraishi, H. Sakamoto, S. Ichikawa, S. Tanaka, T. Hirai, ACS Sustainable Chem. Eng., 2017, 5, 6478-6485.

[26] Y. Kofuji, Y. Isobe, Y. Shiraishi, H. Sakamoto, S. Tanaka, S. Ichikawa, T. Hirai, J. Am. Chem. Soc., 2016, 138, 10019-10025.

[27] A. Naldoni, T. Montini, F. Malara, M. M. Mróz, A. Beltram, T. Virgili, C. L. Boldrini, M. Marelli, I. Romero-Ocaña, J. J. Delgado, V. D. Santo, P. Fornasiero, ACS Catal., 2017, 7, 1270-1278.

[28] R. Li, Y. Weng, X. Zhou, X. Wang, Y. Mi, R. Chong, H. Han, C. Li, En-

\section{Graphical Abstract}

Chin. J. Catal., 2019, 40: 470-475 doi: S1872-2067(19)63274-2

\section{Simultaneous hydrogen and peroxide production by photocatalytic water splitting}

Lichao Wang, Shuang Cao, Kai Guo, Zhijiao Wu, Zhi Ma*, Lingyu Piao*

National Center for Nanoscience and Technology; Tianjin University

Photocatalytic water splitting into hydrogen and peroxide, two value-added chemicals, is achieved over a $\mathrm{Pt} / \mathrm{TiO}_{2}$ (anatase) photocatalyst, avoiding separation problems.

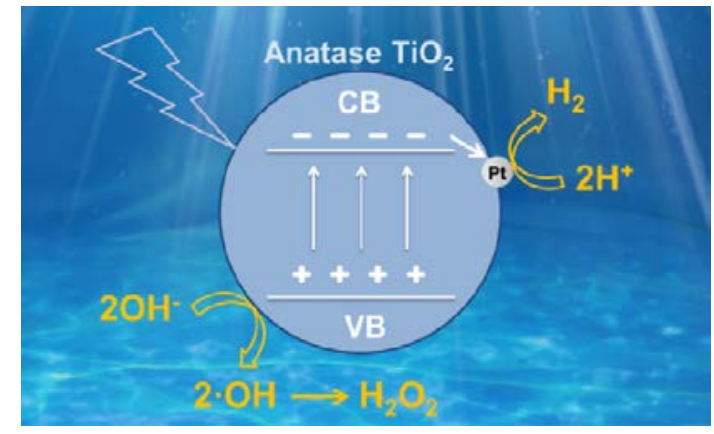


ergy Environ. Sci., 2015, 8, 2377-2382.

[29] K. Maeda, Chem. Commun., 2013, 49, 8404-8406.

[30] V. M. Daskalaki, P. Panagiotopoulou, D. I. Kondarides, Chem. Eng. J., 2011, 170, 433-439.

[31] J. Liu, Y. Zhang, L. Lu, G. Wu, W. Chen, Chem. Commun., 2012, 48, 8826-8828.

[32] Z. Wu, S. Cao, C. Zhang, L. Piao, Nanotechnology, 2017, 28, 275706/1-275706/12.

[33] Z. Li, B. Tian, W. Zhen, Y. Wu, G. Lu, Appl. Catal. B, 2017, 203, 408-415.

[34] M. Liu, L. Piao, W. Lu, S. Ju, C. Zhou, H. Li, W. Wang, Nanoscale, 2010, 2, 1115-1117.

[35] M. Liu, M. Zhong, H. Li, L. Piao, W. Wang, ChemPlusChem, 2015, 80, 688-696.

[36] M. A. Khalily, H. Eren, S. Akbayrak, H. H. Susapto, N. Biyikli, S. Özkar, M. O. Guler, Angew. Chem. Int. Ed., 2016, 55, 12257-12261.
[37] D. Wang, Z. P. Liu, W. M. Yang, ACS Catal., 2017, 7, 2744-2752.

[38] J. Cai, M. Wu, Y. Wang, H. Zhang, M. Meng, Y. Tian, X. Li, J. Zhang, L. Zheng, J. Gong, Chem, 2017, 2, 877-892.

[39] T. D. Nguyen-Phan, S. Luo, Z. Liu, A. D. Gamalski, J. Tao, W. Xu, E. A. Stach, D. E. Polyansky, S. D. Senanayake, E. Fujita, J. A. Rodriguez, Chem. Mater., 2015, 27, 6281-6296.

[40] Z. Wei, D. Liu, W. Wei, X. Chen, Q. Han, W. Yao, X. Ma, Y. Zhu, ACS Appl. Mater. Interfaces, 2017, 9, 15533-15540.

[41] J. J. Wang, Z. J. Li, X. B. Li, X. B. Fan, Q. Y. Meng, S. Yu, C. B. Li, J. X. Li, C. H. Tung, L. Z. Wu, ChemSusChem, 2014, 7, 1468-1475.

[42] S. Cao, Y. Chen, H. Wang, J. Chen, X. Shi, H. Li, P. Cheng, X. Liu, M. Liu, L. Piao, Joule, 2018, 2, 549-557.

[43] T. Tachikawa, M. Fujitsuka, T. Majima, J. Phys. Chem. C, 2007, 111, 5295-5275.

[44] X. Li, J. Yu, M. Jaroniec, Chem. Soc. Rev., 2016, 45, 2603-2636.

[45] K. Sayama, H. Arakawa, J. Chem. Soc., Faraday Trans., 1997, 93, $1647-1654$.

\section{光催化分解水制备氢气和过氧化氢

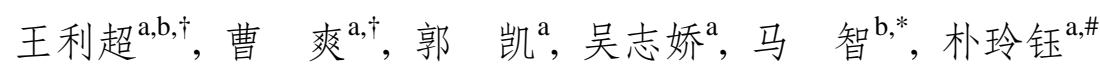 \\ a国家纳米科学中心, 中国科学院纳米科学卓越创新中心, 中国科学院纳米标准与检测重点实验室, 北京100190 \\ b 天津大学化工学院催化科学与工程系, 天津 300072}

摘要: 过氧化氢不仅是一种广泛应用于化学合成、消毒、废水处理及纸浆漂白等领域的高价值化学品, 还是一种具有潜力 的能源载体. 此外, 过氧化氢燃料电池因其结构简单而受到广泛关注. 葱醌法是工业生产过氧化氢的传统方法, 但是这种 方法不仅能耗高, 而且生产过程会造成严重的环境问题. 因此, 通过环保并且低成本的工艺直接合成过氧化氢具有重要研 究意义. 以太阳能为动力的光催化法生产过氧化氢被认为是最有前景的方法之一. 目前, 光催化已在制氢、二氧化碳还原 和水处理等诸多领域取得了重要进展. 但是,利用光催化分解水制备过氧化氢的研究还非常少. 尽管通过光催化还原氧气 可以制备过氧化氢, 但是通过分解水同时制备高价值过氧化氢和氢气更具有吸引力.

在本项工作中, 我们利用 $\mathrm{Pt} / \mathrm{TiO}_{2}$ (锐钣矿)光催化剂在没有牺牲剂的条件下实现了高效产氢和过氧化氢, 氢气和过氧化 氢的生成速率分别达到 7410 和 $5096 \mu \mathrm{mol} \mathrm{g}^{-1} \mathrm{~h}^{-1}$ (第一小时), 远高于市售的 $\mathrm{Pt} / \mathrm{TiO}_{2}$ (锐钛矿)体系和文献报道数值. 本文采用 $\mathrm{X}$ 射线光电子能谱(XPS)、电子自旋共振 $(\mathrm{ESR})$ 和荧光标记法等表征手段研究了 $\mathrm{P} t / \mathrm{TiO}_{2}$ 上同时生成氢气和过氧化氢的催化 机理.

$\mathrm{XPS}$ 测试结果表明, Pt/TiO 在光照射 $1 \mathrm{~h}$ 后, XPS信号发生明显变化. 与其他样品相比, 物理吸附水和羟基的峰明显增 加. 因此, 我们推测差基和物理吸附水对过氧化氢的生成具有重要影响. 进一步采用电子自旋共振(ESR)和荧光标记法对 羟基进行了测量. ESR 结果显示, 紫外光照 $60 \mathrm{~s}$ 即可检测到羟基捕获剂与羟基的结合物5,5-dimethyl-1-pyrroline-N-oxide-OH (DMPO-OH)的特征峰. 此外, 在体系中加入苂光标记分子对苯二甲酸(TANa)后也可以迅速检测到2-羟基对苯二甲酸 $(\mathrm{TAOH})$ 在 $422 \mathrm{~nm}$ 处明显的荧光信号. 因此, ESR 和荧光结果均表明所产生的羟基自由基在过氧化氢形成中起着重要作用.

上述结果表明, 在本体系中氢气和过氧化氢的生成遵循两电子转移过程. 与传统全分解水体系生成氢气和氧气相比, 两电子转移过程比四电子过程更容易发生. 因此, 光催化水氧化制过氧化氢是实现大规模生产氢气和过氧化氢的一种很 有前景的方法.

关键词：光催化分解水; 氢气; 过氧化氢; 锐铁矿

收稿日期: 2018-11-05. 接受日期: 2018-12-07. 出版日期: 2019-03-05.

*通讯联系人. 电话: (022)27403389; 电子信箱: mazhi@tju.edu.cn

\#通讯联系人. 电话: (010)82545653; 电子信箱: piaoly@nanoctr.cn

基金来源：国家自然科学基金(21703046); 国家重点研发计划(2016YFF0203803, 2016YFA0200902).

本文的电子版全文由Elsevier出版社在ScienceDirect上出版(http://www.sciencedirect.com/science/journal/18722067). 